UDC 621.941-229.3:621.822.172

DOI: 10.25140/2411-5363-2020-4(22)-42-47

\author{
Peter Marcinko, Juraj Koščák
}

\title{
EXPERIMENTAL METHOD FOR VERIFICATION OF PERFORMANCE CRITERIA OF THE INDUSTRIAL ROBOTS
}

\begin{abstract}
Urgency of the research. The interest in this issue is growing. By creating a suitable solution, it is possible to detect damage to the robot. Based on the 9283 standard, a methodology was proposed, according to which it is possible to experimentally measure the working characteristics of industrial robots.

Target setting. The main goal was to design a methodology on the basis of which methodological sheets could be developed and to develop and evaluate experimental measurements with the help of these sheets.

Actual scientific researches and issues analysis. Analysis of the publications shows that at present the data acquisition systems about the working characteristics of industrial robots are currently very expensive. These systems use laser interference method.

Uninvestigated parts of general matters defining. This paper is focused on the analysis of a suitable method and the creation of measuring devices for experimental measurements.

The research objective. The aim of this research was to create a methodology for measuring quantities. Creation of suitable means and subsequent evaluation of measured values. Data collection using Matlab software should be improved in the future.

The statement of basic materials. The analysis consists of the ISO 9283 standard. After a thorough analysis, methodological sheets and measuring devices such as measuring nest were created.

Conclusions. Since there is a robot in the department with positioning inaccuracies, it was decided to try to create a suitable tool that would be able to analyse this robot in more detail and obtain data on working characteristics.

Keywords: mechanical vibration; mechanical systems; damage; vibrodiagnostics.

Fig.: 4. Table: 2. References: 8 .
\end{abstract}

Problem definition. Robotics covers the areas of development, research, design and use of robots. It combines knowledge from several scientific disciplines from mathematics, electrical engineering, mechanical engineering, economic to biology. In recent decades, various materials and new technologies have been developed. The deployment of all new robotic applications in which the performance requirements of robots change frequently is closely related to this. Manufacturers are constantly striving to improve production processes to reduce errors and costs. These requirements are taken into account when deploying robotic applications [1].

The most important factors in choosing the correct robot are the accuracy and repeatability of the robot. The choice of the correct robot to perform the intended task consists in getting to know all the working characteristics of the robot in the whole degree of work deployment. One of the other problems is the economic side of the deployed robot. Small companies do not have the capital to provide a new, fully functional robot that can be safely deployed in a robotic application, so it is often the case that small companies are indirectly forced to buy a robot that has already been deployed in operation [2].

It often happens that these used robots are already on the verge of usability. It often happens that the information about the use of the robot is unknown, and this also applies to the maintenance data. Sometimes a robot has a collision with an object in its workspace and this leads to deformation of the arm or damage to other parts. The robot could work at higher loads than prescribed by the manufacturer, which affects the wear of the joints and this leads to a deterioration in the repeatability and overall accuracy of the robot [3].

By measuring the working characteristics of the robot, it is possible to determine the overall condition of the robot and then it is appropriate to evaluate whether such a robot meets the requirements for its re-deployment in operation [4].

The main standards for robotic systems and their general characteristics, safety and terminology are:

ISO 10218 - safety requirements for industrial robots,

ISO 13482 - safety requirements for personal care robots,

ISO 9283 - performance criteria and related test methods,

ISO 9787 - coordinate systems and motion nomenclatures.

(C) Петер Марцінко, Юрай Кощак, 2020 


\section{TECHNICAL SCIENCES AND TECHNOLOGIES}

Overview of the standard for experimental measurements. The measured object was an industrial robot of the Scara kinematic structure from the manufacturer Yamaha. This robot is integrated into the educational process and is used mainly for handling operations in laboratory conditions. These measurements were subject to the ISO 9283 standard and are described in more detail at Table 1 [3].

Table 1

Overview of ISO 9283

\begin{tabular}{|c|c|c|c|c|c|c|c|}
\hline \multirow[t]{2}{*}{ Charakteristics } & \multicolumn{2}{|c|}{$\begin{array}{c}\text { Load } \\
\text { (\% nominal } \\
\text { value) }\end{array}$} & \multicolumn{3}{|c|}{$\begin{array}{c}\text { Speed } \\
\text { (\% nominal value) }\end{array}$} & \multirow[t]{2}{*}{$\begin{array}{l}\text { Number } \\
\text { of cycles }\end{array}$} & \multirow[t]{2}{*}{$\begin{array}{l}\text { Positions (on the } \\
\text { measuring plane) }\end{array}$} \\
\hline & $50 \%$ & $100 \%$ & $10 \%$ & $50 \%$ & $100 \%$ & & \\
\hline 1. Pose accuracy & $\nabla$ & & $\nabla$ & $\nabla$ & & 30 & $P_{1}-P_{2}-P_{3}-P_{4}-P_{5}$ \\
\hline 2. Pose repeatability & $\nabla$ & & $\nabla$ & $\nabla$ & & 30 & $P_{1}-P_{2}-P_{3}-P_{4}-P_{5}$ \\
\hline 3. Distance accuracy and distance repeatability & $\nabla$ & & $\nabla$ & $\nabla$ & & 30 & $P_{1}-P_{2}-P_{4}$ \\
\hline 4. Distance accuracy & $\square$ & & $\nabla$ & $\nabla$ & & 30 & $\mathrm{P}_{2}-\mathrm{P}_{4}$ \\
\hline 5. Distance repeatability & $\square$ & & $\nabla$ & $\nabla$ & & 30 & $\mathrm{P}_{2}-\mathrm{P}_{4}$ \\
\hline 6. Position stabilization time & $\nabla$ & & $\nabla$ & $\nabla$ & & 3 & $P_{1}-P_{2}-P_{3}-P_{4}-P_{5}$ \\
\hline 7. Position overshoot & $\nabla$ & & $\nabla$ & $\nabla$ & & 3 & $P_{1}-P_{2}-P_{3}-P_{4}-P_{5}$ \\
\hline 8. Drift pose accuracy & $\square$ & & $\square$ & [ & & $*$ & $\mathrm{P}_{1}$ \\
\hline 9. Drift pose repeatability & $\square$ & & $\square$ & & & $*$ & $P_{1}$ \\
\hline 10. Path accuracy & $\nabla$ & & & & & 10 & ** \\
\hline 11. Path repeatability & $\nabla$ & & & & & 10 & ** \\
\hline 12. Cornering round-off error & $\square$ & & & & & 3 & $E_{1}-E_{2}-E_{3}-E_{4}$ \\
\hline 13. Cornering overshoot & $\square$ & & & & & 3 & $E_{1}-E_{2}-E_{3}-E_{4}$ \\
\hline 14. Weaving stroke error & $\square$ & & & & & 3 & $E_{1}-E_{2}-E_{3}-E_{4}$ \\
\hline 15. Path velocity accuracy & $\nabla$ & & $\nabla$ & & & 10 & ** \\
\hline 16. Path velocity repeatability & $\nabla$ & & $\nabla$ & & & 10 & ** \\
\hline 17. Path velocity fluctuation & $\nabla$ & & $\nabla$ & & & 10 & $* *$ \\
\hline 18. Minimum posing time & $\nabla$ & & $\square$ & $\nabla$ & & 3 & $* * *$ \\
\hline 19. Static compliance & & $<* *$ & & & & 3 & $P_{1}$ \\
\hline
\end{tabular}

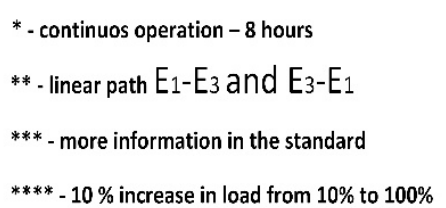

\begin{tabular}{|ll|}
\hline$\square$ & - non - required \\
\hline $\boldsymbol{D}$ & - optional \\
\hline $\boldsymbol{D}$ & - required \\
\hline
\end{tabular}

Conditions of measuring. The conditions for carrying out the measurement must be in accordance with the manufacturer's recommendations, in particular as regards installation. The robot should be functional and, according to the manufacturer, properly mounted and all balancing should be satisfactory. If a warm-up operation is specified, it should be performed. The standard specifies an ambient temperature of $(20 \pm 2){ }^{\circ} \mathrm{C}$ or in the range of 5 to $40{ }^{\circ} \mathrm{C}$ [5].

Measurements were performed at an ambient temperature of $20^{\circ} \mathrm{C}$ on an industrial robot UR5 with an appropriate control box and control pendant. The verification was performed using a mechanical connection of a flange and a load of $5 \mathrm{~kg}$. The measured points on a given measured plane were also determined by the standard and the location of the measuring cube and the 
measuring ball. The test cycles were in accordance with the standard. The vertices $\mathrm{C} 1$ to $\mathrm{C} 8$ denote the vertices of a simple cube, which is located in the part of the working space where the most frequent use of the robot is assumed, Fig. 2.

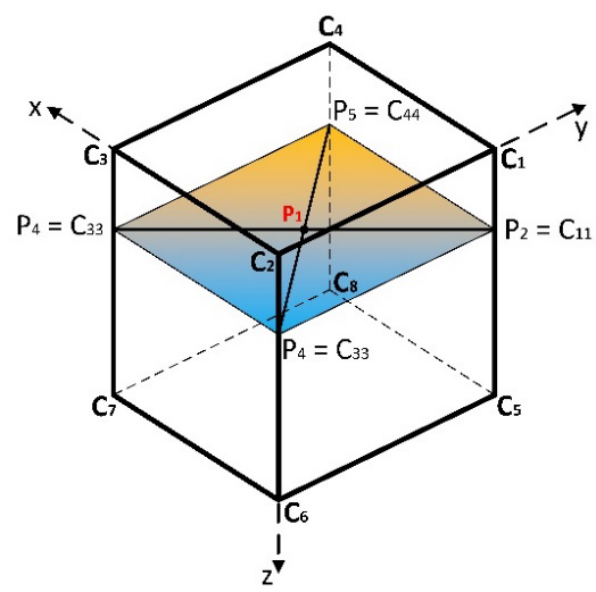

Fig. 1. Measuring plane

Measuring object. The measurements were performed on an industrial robot of atypical kinematic structure, Scara from Yamaha. It is an industrial robot that is flexible in the $\mathrm{x}$ and $\mathrm{y}$ axes and fixed in the $\mathrm{z}$ axis. From the point of view of the proposed construction, this structure should handle demanding operations with the object of manipulation. An available Yamaha YK-600X robot, Fig. 3 with QRCX-RCX 240 controller, was used for measurements. The robotic device consists of three basic parts [6]:

- industrial robot,

- controller,

- teach pendant.

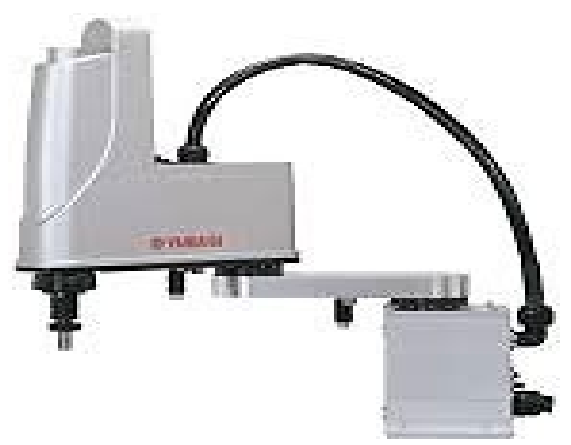

Fig. 2. Yamaha YK $600 X$

In technical practice, this method is the most used, it is a method that uses measurements of geometry parameters of spatial mechanisms. The basis is the measurement of the deviation of the achieved (actual) position and orientation of the reference body in the working space of the mechanism from the programmed (desired) position. This body can have different shapes.

In the mentioned measurements, a cube or a sphere is used (so-called calibration mandrels are also used). The method is based on measuring the change in position and orientation of a reference body in space. The measuring cube must be geometrically accurate (polished) and is used to measure position and orientation. The measuring ball must also be geometrically accurate for position measurements. These bodies are mechanically attached to the robot interface (mechanical connection). The second method, which was used in the performed measurements, was the method of measuring with a cubic reference body, i.e. the so-called measuring cube. This method involves placing the housing in a measuring socket where the sensors are clamped [7]. 
TECHNICAL SCIENCES AND TECHNOLOGIES

The measurements were performed by stopping the body at the test point during the first cycle, which made it possible to reset all sensors. Plate stops were fitted at the ends of the sensors. The next step was to run a program that guaranteed repeated entry and exit of the body into the measuring nest. This gave deviation values from the first reference value. Measuring nest with measuring ball is shown at Fig. 4.

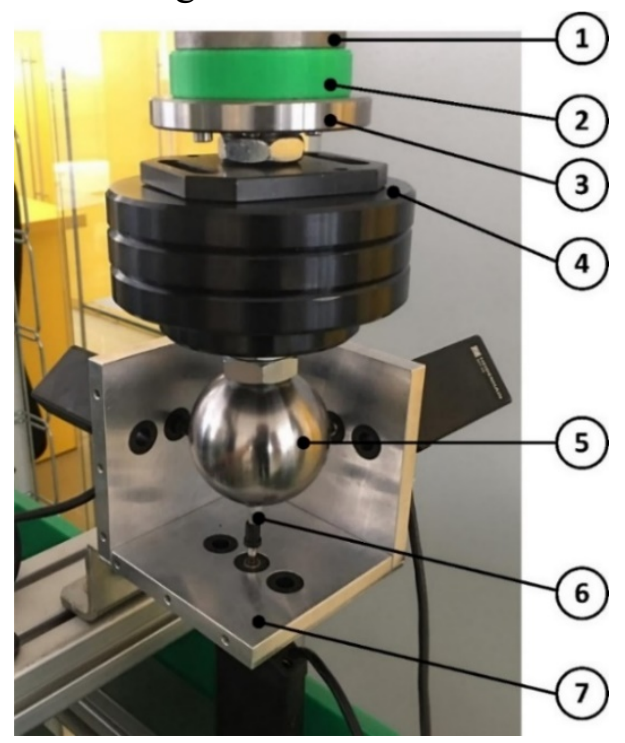

Fig. 3. Measuring of robot Scara

Parts of realized measuring:

1) end flange of robot,

2) intermediate flange,

3) flange of measuring parts,

4) nominal load,

5) measuring ball,

6) sensor

7) measuring nest.

Experimental measuring. Formulas from the standard were used to calculate all values. We focused mainly on the values of these working characteristics: pose accuracy, pose repeatability, drift pose accuracy and drift pose repeatability. Overall, the measurements were tested on industrial robots, which did not show any deviation during manipulation or simulation. The measurements were evaluated as satisfactory and therefore this methodology was applied to a Scara robot [8].

Pose accuracy measurements were performed at five points with $100 \%$ load and $100 \%$ speed. 30 measurements were performed and Tab. 2 shows the calculated values.

Table 2

Values of $A P$

\begin{tabular}{|c|c|c|c|c|c|}
\hline N.m. & P1 & P2 & P3 & P4 & P5 \\
\hline 1 & 2 & 3 & 4 & 5 & 6 \\
\hline 1. & 0,0255999349 & 0,0084903213 & 0,0046888757 & 0,0035744463 & 0,0089612747 \\
\hline 2. & 0,0142626552 & 0,0065027345 & 0,0042093811 & 0,0029399546 & 0,0022886192 \\
\hline 3. & 0,0113117933 & 0,0118216844 & 0,0038103660 & 0,0028711206 & 0,0028468306 \\
\hline 4. & 0,0051791248 & 0,0063313155 & 0,0072745370 & 0,0045727453 & 0,0039880377 \\
\hline 5. & 0,0127732794 & 0,0063049363 & 0,0052521953 & 0,0045434935 & 0,0039206009 \\
\hline 6. & 0,0087952639 & 0,0036173962 & 0,0008863157 & 0,0018556221 & 0,0085188679 \\
\hline 7. & 0,0297661441 & 0,0033593981 & 0,0046027769 & 0,0054506880 & 0,0079059752 \\
\hline 8. & 0,0070064256 & 0,0056289924 & 0,0054023657 & 0,0061625211 & 0,0085773604 \\
\hline 9. & 0,0118500352 & 0,0071006260 & 0,0060541079 & 0,0015842980 & 0,0085812457 \\
\hline 10. & 0,0137388743 & 0,0028552097 & 0,0050976029 & 0,0028942472 & 0,0070406755 \\
\hline 11. & 0,0090529921 & 0,0059737388 & 0,0096946148 & 0,0030946190 & 0,0039120895 \\
\hline
\end{tabular}


The end of the table 2

\begin{tabular}{|c|c|c|c|c|c|}
\hline 1 & 2 & 3 & 4 & 5 & 6 \\
\hline 12. & 0,0175866427 & 0,0067294543 & 0,0051236922 & 0,0066214299 & 0,0024841721 \\
\hline 13. & 0,0109189438 & 0,0056526297 & 0,0070322274 & 0,0056783213 & 0,0025634179 \\
\hline 14. & 0,0138042264 & 0,0050483221 & 0,0073474863 & 0,0017823206 & 0,0056543002 \\
\hline 15. & 0,0099376389 & 0,0074845767 & 0,0078730906 & 0,0033630343 & 0,0050567886 \\
\hline 16. & 0,0099141313 & 0,0068618915 & 0,0037752115 & 0,0050441385 & 0,0504371336 \\
\hline 17. & 0,0043844422 & 0,0101629501 & 0,0050582166 & 0,0068685273 & 0,0069453422 \\
\hline 18. & 0,0059180515 & 0,0091370430 & 0,0051366872 & 0,0032419130 & 0,0065093096 \\
\hline 19. & 0,0100609807 & 0,0091114702 & 0,0076758640 & 0,0015416441 & 0,0057362396 \\
\hline 20. & 0,0047843495 & 0,0079552219 & 0,0068982284 & 0,0055235858 & 0,0066360966 \\
\hline 21. & 0,0091445795 & 0,0053869183 & 0,0017470610 & 0,0033030289 & 0,0092035017 \\
\hline 22. & 0,0088820043 & 0,0056585236 & 0,0076497640 & 0,0052258971 & 0,0053886712 \\
\hline 23. & 0,0238695762 & 0,0036173962 & 0,0048838737 & 0,0034799425 & 0,0070406755 \\
\hline 24. & 0,0182013736 & 0,0070156175 & 0,0087551255 & 0,0033231511 & 0,0058341904 \\
\hline 25. & 0,0132924791 & 0,0045627721 & 0,0132105597 & 0,0024172988 & 0,0045939574 \\
\hline 26. & 0,0067347358 & 0,0051979697 & 0,0115924784 & 0,0041444742 & 0,0045575334 \\
\hline 27. & 0,0111425610 & 0,0060952623 & 0,0096048020 & 0,0033231511 & 0,0068243030 \\
\hline 28. & 0,0124615408 & 0,0052490211 & 0,0038797193 & 0,0033827996 & 0,0039628833 \\
\hline 29. & 0,0165777964 & 0,0085138449 & 0,0036495053 & 0,0036299679 & 0,0040707630 \\
\hline 30. & 0,0200538442 & 0,0037263327 & 0,0100325581 & 0,0063542637 & 0,0063380684 \\
\hline
\end{tabular}

Altogether, more than 500 measurements were measured, which were then evaluated. The values were plotted.

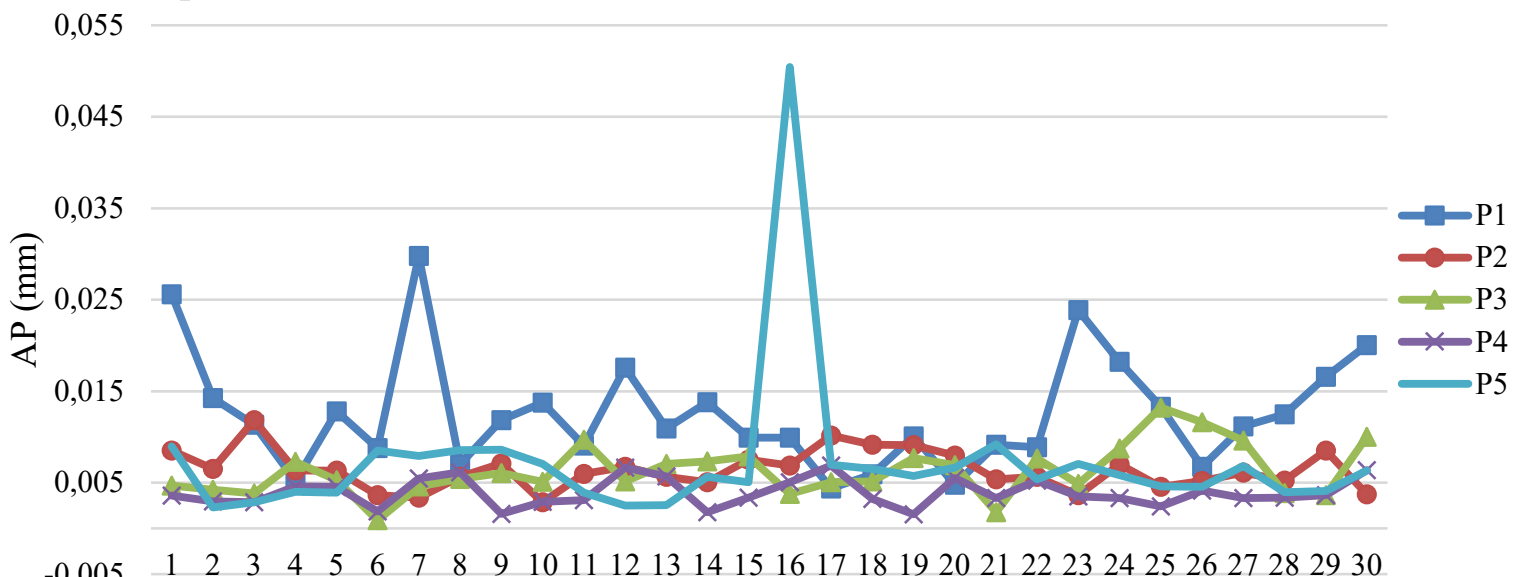

Fig. 4. Graph of plotted values - pose accuracy - AP

The calculated values from the measurements exceed the values specified by the manufacturer, while the measuring point P5 exceeds the values up to three times. This measurement proves that the measured robot exceeds the limits and is thus evaluated as unsatisfactory.

Conclusions. International Standard ISO 9283 further specifies performance criteria for industrial robots and their performance characteristics. The main goal was to design a methodology according to this standard and then test it on a Scara robot. By creating a measuring nest and using the measuring technique, this robot was experimentally verified. Based on the working environment of the robot, the size of the measuring cube or sphere was defined. It was also necessary to create a program according to the required path of movement of the robot, speed, acceleration, but also the number of cycles that were to be repeated. Overall, a large amount of data to be processed has been measured. In the future, it would be possible to improve data collection and thus obtain even larger amount of data.

Acknowledgements. This paper was published in cooperation with company KYBERNETES s.r.o. within the project "Research and development of the ECOGI product at KYBERNETES”, ITMS Code of Project: 313012Q955. 


\section{References}

1. Velíšek, K., Katalinič, B., Javorová, A. 2006. Priemyselné roboty a manipulátory. Slovenská technická univerzita v Bratislave. 183 str. ISBN 80-227-2492-0.

2. Vitralab, Př́ručka: Automatizační a robotická technika, Leonardo da Vinci Programme LLP/LDC/TOI/2009/SK/93100530, Košice, September 2011. Retrieved from http://www.sjf.tuke.sk/vitralab/files/vystupy/prirucka_cz_final.pdf (9.11.2020).

3. Marcinko, P.: Experimentálne pracovisko s robotom SCARA (Experimental workplace with SCARA robot). Dissertation thesis. Technical university of Košice. Košice 2020, 115 str.

4. STN EN ISO 9283. Manipulačné priemyselné roboty. Technické parametre a súvisiace skúšobné metódy. (Manipulating industrial robots. Performance criteria and related test methods).

5. Semjon, J., Sukop, M., Vagas, M., Janos, R., Tuleja, P., Koukolova, L., Marcinko, P., Jurus, O., Varga, J. (2018). Comparison of The Delta Robot ABB IRB 360 Properties After Collisions . Communications - Scientific Letters of the University of Zilina, 20(1), 42-46.

6. Yamaha 4-axis robot controller. RCX 240. User's manual. Retrieved from https://www.yrginc.com/Catalog/PDF/CurrentManuals/CONTROLLER_E/RCX240_UM_E_V2.02.pdf (11.11.2020)

7. Marcinko, P., Semjon, J. Experimentálne pracovisko s robotom Scara. Novus Scientia 2019: zborník príspevkov z 16. medzinárodnej vedeckej konferencie doktorandov strojníckych fakúlt technických univerzít a vysokých škôl. Košice. Technická univerzita v Košiciach, ISBN 978-80-553-32499, str. 107-110.

8. Marcinko, P., Juruš, O.: An experimental workplace with scara robot. Technical Sciences and Technologies. Černihiv (Ukrajina): Chernihiv National University of Technology Roč. 14, č.4 (2018), ISSN 2411-5363, str. 124-130.

УДК 621.941-229.3:621.822.172

Петер Мариінко, Юрай Кощзак

\section{ЕКСПЕРИМЕНТАЛЬНИЙ МЕТОД ДЛЯ ПЕРЕВІРКИ ВИКОНАВЧИХ КРИТЕРІЇВ ПРОМИСЛОВИХ РОБОТІВ}

\footnotetext{
Актуальність теми дослідження. Інтерес до иъього питання зростає. Створивши відповідне рішення, можсна виявити пошкодження робота. На основі стандарту 9283 була запропонована методологія, згідно з якою можна експериментально виміряти робочі характеристики промислових роботів.

Постановка проблеми. Основною метою було розробити методологію, на основі якої можна було б сформувати методологічні рекомендації та за допомогою иих рекомендацій виконати й оцінити експериментальні вимірювання.

Аналіз останніх досліджень і публікацій. Аналіз публікацій показує, що в даний час системи збору даних про робочі характеристики промислових роботів дуже дорогі. У иих системах використовується метод лазерної інтерферениії.

Виділення недосліджених частин загальної проблеми. Ця стаття зосереджена на аналізі релевантного методу та створенні вимірювальних приладів для експериментальних вимірювань.

Постановка завдання. Метою цьвого дослідження було створення методологї̈ вимірювання величин. Створення придатних засобів та подальша оиінка виміряних величин. Збір даних за допомогою програмного забезпечення Маtlab має бути вдосконалений у майбутньому.

Виклад основного матеріалу. Аналіз трунтується на стандарті ISO 9283. Після ретельного аналізу були створені методичні рекомендації та вимірювальні прилади, такі як вимірювальний кут.

Висновки відповідно до статті. Оскільки у відділі є робот із неточностями в позичіюванні, було вирімено спробувати створити відповідний інструмент, який міг би більш детально проаналізувати цей робота та отримати дані про робочі характеристики.

Ключові слова: механічна вібрачія; механічні системи; пошкодження; вібродіагностика.

Рис.: 4. Табл.: 2. Бібл.: 8 .

Peter Marcinko - assistant professor, Technical University of Košice, Faculty of Mechanical Engineering, Department of production systems and robotics (Park Komenského 8, 04200 Košice, Slovakia).

SCOPUS Author ID:57200138054

ORCID: https://orcid.org/0000-0003-2853-5755

E-mail: peter.marcinko@tuke.sk

Juraj Koščák - Designer, KYBERNETES, s.r.o. (Omska 14, 04001 Kosice, Slovakia).

(Юрай Кошчак, Юрай Кощак )

ORCID: https://orcid.org/0000-0002- 7591-1277

E-mail: juraj.koscak@kybernetes.sk
}

Marcinko, P., Koščák, J. (2020). Experimental method for verification of performance criteria of the industrial robots. Technical sciences and technologies, 4(22), pp. 42-47. 